ISSN 1392-3196 / e-ISSN 2335-8947

Zemdirbyste-Agriculture, vol. 106, No. 2 (2019), p. 151-158

DOI 10.13080/z-a.2019.106.020

\title{
In vitro tetraploid induction of the blackcurrant (Ribes nigrum L.) and preliminary phenotypic observations
}

\author{
Małgorzata PODWYSZYŃSKA, Stanisław PLUTA \\ Research Institute of Horticulture \\ Konstytucji 3 Maja 1/3, 96-100 Skierniewice, Poland \\ E-mail: malgorzata.podwyszynska@inhort.pl
}

\begin{abstract}
The aim of this study was to develop an in vitro polyploidisation method for the breeding of new improved cultivars of blackcurrant (Ribes nigrum L.). The Polish blackcurrant cultivars 'Gofert' and 'Polares' were used for the experiments. For polyploidisation, shoot explants were incubated for six days in the dark on a modified Murashige and Skoog medium supplemented with $4.5 \mu \mathrm{M}$ 6-benzylaminopurine (BAP), $0.3 \mu \mathrm{M}$ gibberellic acid $\left(\mathrm{GA}_{3}\right)$ and $0.5 \mu \mathrm{M}$ indole-3-acetic acid (IAA), containing one of the following antimitotic agents: colchicine, trifluralin, oryzalin or amiprophos methyl. The strongest phytotoxic effects of antimitotic agents were observed for trifluralin (all the explants died). Tetraploids were obtained for both cultivars: 21 for 'Gofert' and 12 for 'Polares', respectively. The higher efficiencies of tetraploid induction were recorded with oryzalin $\left(5 \mathrm{mg} \mathrm{L}^{-1}\right)$, $26.3 \%$ and $28.6 \%$ for 'Gofert' and 'Polares', respectively; $25.9 \%$ with colchicine $\left(125 \mathrm{mg} \mathrm{L}^{-1}\right)$ for 'Polares' and $9.3 \%$ with amiprophos methyl $\left(5 \mathrm{mg} \mathrm{L}^{-1}\right)$ for 'Gofert'. In addition, only six $(2.4 \%)$ homogeneous 'Gofert' tetraploids were selected directly. Instead, the high percentage (30.1\%) of mixoploids was detected in this cultivar. All mixoploid shoots were subcultured twice. An additional 15 homogeneous tetraploids were selected based on the flow cytometry analysis from the mixoploid shoot cultures, but only from among those with a predominance of the tetraploid genotype. The polyploidisation efficiency was on average $8.4 \%$ for 'Gofert' and $9.2 \%$ for 'Polares'. In vitro growth and shoot multiplication of newly obtained tetraploids were very poor in the presence of BAP. Therefore, in order to obtain tetraploid shoots capable of rooting, shoot multiplication was optimized by application of 6-(3-hydroxybenzylamino)purine (meta-topolin). Replacement of BAP with meta-topolin in the medium allowed faster multiplication of the newly obtained tetraploids, which were then rooted in vitro and grown in a greenhouse. The tetraploids differed phenotypically from their diploid counterparts. Detailed measurements were done for 'Gofert' after six months of growing plants in vitro. Compared to diploid plants, tetraploids had shorter shoots, they contained fewer leaves, their leaf shape was different and chlorophyll index was higher.
\end{abstract}

Key words: amiprophos methyl, chromosome doubling, colchicine, meta-topolin, oryzalin.

\section{Introduction}

For many years, Poland has been a world leader in the production and export of blackcurrant (Ribes nigrum L.) fruits. In recent years, the annual domestic production of blackcurrant fruits has ranged from 124 to 155 thousand metric tons (GUS, 2017). Such a large production is due to the implementation of technological and biological progress, especially with new and valuable cultivars. They should be characterized by a high production value with good fruit quality and be resistant to economically dangerous pests and diseases as well as adapt well to local climate and soil conditions and meet the basic requirements of mechanical fruit harvesting (Pluta, 2012). Currently, cultivars of blackcurrant with unique dessert fruit quality are highly sought (Pluta et al., 2012). Such cultivars should be characterized by large attractive fruits and also have high nutritional and health benefit value. Genotypes with larger and tastier fruits may be produced using traditional (cross-hybridization) breeding and polyploidisation. The polyploidisation process is one of the important sources of genetic variation, and genotypes of the multiplied chromosome numbers are widely used in breeding programs of many plants (Mason, 2016; Sattler et al., 2016). Among the most commonly observed features of newly obtained polyploids (usually triploids and tetraploids), compared to the diploids, are larger sizes of various organs, including fruits that were reported for tetraploids of, e.g., Cucumis melo (Zhang et al., 2010) and Actinidia chinensis (Wu et al., 2012). In addition, fruits of polyploids are usually characterized by delicate flesh. This is because the polyploid cells are much larger than their diploid counterparts and therefore have a higher ratio of the cytoplasm volume to the cell wall. Triploids of many species often have seedless fruits or fruits with reduced seed numbers (Sattler et al., 2016). Good examples of such triploid cultivars are seedless grapes (Reisch et al., 2012), watermelons (Mason, 2016)

Please use the following format when citing the article:

Podwyszyńska M., Pluta S. 2019. In vitro tetraploid induction of the blackcurrant (Ribes nigrum L.) and preliminary phenotypic observations. Zemdirbyste-Agriculture, 106 (2): 151-158. DOI 10.13080/z-a.2019.106.020 
and bananas (D’Hont et al., 2012), which are commonly found on the market. In addition to phenotypic alteration, newly obtained autotetraploids can also exhibit novel physiological characteristics such as improved resistance to various diseases, which was reported for several species, for example, in apple (Hias et al., 2018) but also in blackcurrant (Brennan, 1996).

One of the chromosome doubling methods is to induce mitotic polyploids using in vitro techniques considered more effective than in vivo methods (Mason, 2016). However, there are just a few reports concerning the in vitro induction of blackcurrant polyploids (Stanys et al., 2004; Sasnauskas et al., 2007). All natural species of the genus Ribes are diploid $(2 \mathrm{n}=2 \mathrm{x}=16)$ (Chiche et al., 2003). The first hybrid allotetraploid cultivars were developed in the 1970s (Chuvashina, 1980; Bauer, 1986). Also several autotetraploids of blackcurrant were produced in the second half of the last century as reviewed by Brennan (1996) and Hjalmarsson and Wallace (2007). The reported tetraploids were induced in vivo by the treatment of axillary buds with colchicine. Some of these tetraploids were characterized by a later flowering and fruit ripening, higher disease resistance and larger fruits of higher quality (Chuvashina, 1980; Brennan, 1996). The only available articles on in vitro blackcurrant mitotic polyploidisation relate to the treatment of axillary shoots and isolated embryos of interspecific hybrids with antimitotic agents such as colchicine and oryzalin (Stanys et al., 2004; Sasnauskas et al., 2007).

Most of the studies on the in vitro culture of blackcurrant involved micropropagation by axillary shoots in the presence of 6-benzylaminopurine (BAP) (Dziedzic, Jagła, 2012; Sedlak, Paprštein, 2012; Vujović et al., 2012). Other studies were related to the formation of blackcurrant callus (Enevoldsen, 1994) and adventitious shoot regeneration from leaves (Lazić, Ružić, 2007), with the latter used for genetic transformation (Karjalainen et al., 2001). These authors indicated that in Ribes sp. leaves had very low organogenic potential. Therefore, in our studies, shoots were used for polyploidization. It was expected that this type of explants is more useful for this purpose.

The aim of the present research was to develop an in vitro polyploidisation method of blackcurrants to create genotypes that could be used in breeding of new cultivars with new valuable traits such as enhanced resistance to diseases and larger fruits.

\section{Materials and methods}

Research was carried out in 2015-2017 in the Research Institute of Horticulture, in Skierniewice, Poland.

Plant material and shoot multiplication. Two blackcurrant (Ribes nigrum L.) cultivars 'Gofert' and 'Polares' were used for the study. These cultivars are resistant to powdery mildew (Podosphaera mors-uvae Schw.) and white pine blister rust (Cronartium ribicola Fish.). Additionally, 'Polares' is genetically resistant to blackcurrant gall mite (Cecidophyopsis ribis West.) (Pluta, Żurawicz, 2014; 2015).

In vitro shoot cultures were established and multiplied by axillary shoot production. Shoots were established from axillary buds and continuously multiplied in vitro at 4- to 5-week subculture periods in $100 \mathrm{ml}$ Erlenmeyer flasks, containing $25 \mathrm{ml}$ of standard multiplication medium, including modified Murashige and Skoog (1962) macro- and micro-elements. In the medium, $\mathrm{NH}_{4} \mathrm{NO}_{3}$ was reduced to half and the iron source was changed for chelate EDDHA $80 \mathrm{mg} \mathrm{L}^{-1}$; the medium contained $3 \%$ sucrose, $80 \mathrm{mg} \mathrm{L}^{-1}$ adenine sulphate, $2 \mathrm{mg} \mathrm{L}^{-1}$ glycine, $100 \mathrm{mg} \mathrm{L}^{-1}$ inositol, vitamins (thiamine, nicotinic acid and pyridoxine, each at $1 \mathrm{mg} \mathrm{L}^{-1}$ ) and plant growth regulators: $4.5 \mu \mathrm{M}$ 6-benzylaminopurine (BAP), $0.3 \mu \mathrm{M}$ gibberellic acid $\left(\mathrm{GA}_{3}\right)$ and $0.5 \mu \mathrm{M}$ indole-3acetic acid (IAA), $\mathrm{pH} 5.6$ and solidified with $6 \mathrm{~g} \mathrm{~L}^{-1}$ agar Lab-agar (Biocorp, Poland). Such a basic medium, with the exception of growth regulators, was used throughout the experiments.

Shoot cultures in all the experiments, except when stated, were maintained at the temperature of $21^{\circ} \mathrm{C}$ under the standard $16 / 8 \mathrm{~h}$ photoperiod of $30 \mu \mathrm{mol} \mathrm{m} \mathrm{m}^{-2} \mathrm{~s}^{-1}$ photosynthetic photon flux density (warm white fluorescent lamps).

Polyploidisation. Shoots derived from the fourweek cultures with BAP were incubated in the dark for 6 days on a multiplication medium containing $4.5 \mu \mathrm{M}$ BAP and one of the antimitotic agents: colchicine (125 and $\left.250 \mathrm{mg} \mathrm{L}^{-1}\right)$, trifluralin (50 and $\left.100 \mathrm{mg} \mathrm{L}^{-1}\right)$, oryzalin (5 and $10 \mathrm{mg} \mathrm{L}^{-1}$ ) and amiprophos methyl (5 and $10 \mathrm{mg} \mathrm{L}^{-1}$ ). In the control, the medium did not contain any antimitotic agents. The exposure time and concentrations of antimitotic agents were chosen based on our earlier studies in which we found such treatments as optimal for in vitro polyploidisation of other plant species (Podwyszyńska, 2012; Podwyszyńska et al., 2015; 2017). Explants were then transferred to the same medium, but without antimitotic agents, and cultured in the dark for four weeks. Subsequently, shoots were subcultured three times at four-week intervals on a multiplication medium in the standard photoperiod.

Phytotoxic effects of antimitotic agents were evaluated eight weeks after treatments by estimation of percentage of viable explants forming shoots and number of shoots per explant. After the third, fourth and fifth subcultures on multiplication medium, the regenerated shoots were analysed for ploidy level using flow cytometry (FCM) in order to select tetraploids and mixoploids. In turn, all the mixoploid shoots were subcultured twice; each time, the branched shoots were divided into single shoots and analysed again by FCM in order to detect homogeneous tetraploids. Polyploidisation efficiency was calculated as percentage of selected tetraploids of total number of shoots obtained (all regenerated shoots were tested). Additionally, all selected tetraploids were analysed twice with FCM (after next subcultures) in order to exclude mixoploidy.

Flow cytometry (FCM). Samples (1-2 leaves and shoot base) were taken from all the shoots obtained. Plant tissue was chopped in a Petri dish in $0.5 \mathrm{ml}$ nuclei isolation Partec buffer with $1 \%$ polyvinylpyrrolidone (PVP), to which $50 \mu \mathrm{g} \mathrm{ml}^{-1}$ 4',6-diamidino-2-phenylindole (DAPI) was added (Podwyszyńska et al., 2017). After adding $1 \mathrm{ml}$ of the isolation buffer, the samples were filtered through a 30- $\mu \mathrm{m}$ filter and incubated for 45-60 $\mathrm{min}$ in the dark at room temperature. The fluorescence of the nuclei was measured using a CyFlow ploidy analyser (Partec, Germany) with software CyView (CyFlow PA, Partec) with UV-LED $365 \mathrm{~nm}$. The data were analysed by means of software CyView (Partec). Samples with at least 1,000 nuclei were measured. 
Tetraploid micropropagation, rooting, growing in greenhouse and phenotype evaluation. Since poor multiplication and quality of tetraploid shoots was obtained using BAP, the effect of 6-(3-hydroxybenzylamino) purine (meta-topolin) on shoot growth was tested in order to obtain tetraploid shoots capable of rooting. Shoots of the cultivar 'Gofert' were used because of their larger number allowing for the experiment. The basic medium was supplemented with meta-topolin of 2, 4 and $8 \mu \mathrm{M}$. In the control, BAP was used at the standard concentration of $4 \mu \mathrm{M}$. The multiplication rate (number of shoots obtained from a single primary shoot) was measured at the end of a five-week subculture. These experiments were repeated twice.

Selected tetraploids of both cultivars were miropropagated to 5-15 shoots on the multiplication medium in which BAP was replaced by meta-topolin $(8 \mu \mathrm{M})$. Shoots approximately $1 \mathrm{~cm}$ in length, taken at the fifth-week subculture, were cultured on a rooting medium containing MS basic medium excluding adenine sulphate and $\mathrm{NH}_{4} \mathrm{NO}_{3}$ and supplemented with $5 \mu \mathrm{M}$ IAA. After an in vitro rooting period of 21-28 days, the rooting percentage was calculated and plants were planted in paper pots of $30 \mathrm{~mm}$ diameter, with peat-coconut substrate (Ceres International, Poland), in plastic minigreenhouses with two adjustable vent holes to control the humidity. Plants in mini-greenhouses were kept during the first four weeks in a growth chamber under fluorescent lamps $\left(50 \mu \mathrm{mol} \mathrm{m} \mathrm{m}^{-1}\right)$ at $23^{\circ} \mathrm{C}$, and then transferred to the greenhouse for further growing. Plants were manually watered and humidity was reduced gradually by opening vents. Percentage of plant survival was evaluated after a six-week ex vitro growing. Next, young plants were planted into small pots $(7 \times 7 \times 9 \mathrm{~cm})$. Finally, after two consecutive months, plants were transplanted into bigger pots $(12 \times 12 \times 20 \mathrm{~cm})$ for further cultivation. After six months of growing in greenhouse conditions, the plants were evaluated for their phenotype. The following measurements were carried out: length of main shoot, shoot diameter ( $5 \mathrm{~cm}$ from the bottom), number of leaves and branches as well as relative chlorophyll content (SPAD) of leaves. The SPAD as a ratio of optical transmission at $931 \mathrm{~nm}$ divided by transmission at 653 $\mathrm{nm}$ was performed using the chlorophyll meter SPAD502 (Minolta). Measurements were done for two leaves of each plant with three replications per leaf, and means from each plant were taken for analysis of variance. Shoots of diploids were also multiplied, rooted in vitro in the similar way as tetraploids, and plants were grown in the same greenhouse conditions for the phenotype comparison. Twenty plants per each ploidy level were observed. Detailed observations were performed for the cultivar 'Gofert' due to higher number of tetraploid plants that made it possible to perform a statistical analysis of the results.

Statistical analysis. In all the experiments on polyploidisation and shoot multiplication, there were five replications per treatment, i.e. five Erlenmeyer flasks containing 6 shoots (in total, 30 shoots per treatment). For phenotype observation, 20 diploid and 20 tetraploid plants were used. The data were subjected to one-way or two-way analysis of variance (ANOVA), package STATISTICA, version 10 (StatSoft Inc., USA). The means were compared by Duncans's test at $p=0.05$.

\section{Results}

The strongest phytotoxic effects of antimitotic agents were observed for trifluralin and oryzalin (Table 1, Fig. 1). The observations done eight weeks after antimitotic treatments showed that these agents at higher concentrations significantly decreased the shoot survival of both cultivars to approximately $60 \%$ and the multiplication rate below 1.0 (irrespective of concentration). In the control, shoot survival was $100 \%$ and multiplication rates were 2.1 for 'Gofert' and 3.3 for 'Polares'. Unfortunately, shoots of both cultivars treated with trifluralin died approximately 10 weeks

Table 1. Effect of antimitotic agents on shoot survival and multiplication rate of blackcurrant cultivars 'Gofert' and 'Polares'

\begin{tabular}{lcccc}
\hline \multirow{2}{*}{$\begin{array}{c}\text { Antimitotic agents } \\
\text { mg L-1 }\end{array}$} & \multicolumn{2}{c}{$\begin{array}{c}\text { Shoot survival } \\
\text { \% }\end{array}$} & \multicolumn{2}{c}{$\begin{array}{c}\text { Multiplication } \\
\text { rate }\end{array}$} \\
\cline { 2 - 5 } & 'Gofert' & 'Polares' 'Gofert' 'Polares' \\
\hline Control & $100.0 \mathrm{a}$ & $100.0 \mathrm{a}$ & $2.1 \mathrm{a}$ & $3.3 \mathrm{a}$ \\
Colchicine 125 & $92.0 \mathrm{a}$ & $100.0 \mathrm{a}$ & $1.8 \mathrm{ab}$ & $1.6 \mathrm{bc}$ \\
Colchicine 250 & $96.0 \mathrm{a}$ & $100.0 \mathrm{a}$ & $1.6 \mathrm{abc}$ & $2.4 \mathrm{~b}$ \\
Trifluralin 50 & $88.5 \mathrm{a}$ & $50.0 \mathrm{c}$ & $0.9 \mathrm{~cd}$ & $0.8 \mathrm{c}$ \\
Trifluralin 100 & $60.0 \mathrm{~b}$ & $87.5 \mathrm{ab}$ & $0.7 \mathrm{~d}$ & $0.9 \mathrm{c}$ \\
Oryzalin 5 & $88.0 \mathrm{a}$ & $62.5 \mathrm{bc}$ & $1.2 \mathrm{bcd}$ & $0.7 \mathrm{c}$ \\
Oryzalin 10 & $60.0 \mathrm{~b}$ & $62.5 \mathrm{bc}$ & $0.6 \mathrm{~d}$ & $0.9 \mathrm{c}$ \\
Amiprophos methyl 5 & $100.0 \mathrm{a}$ & $62.5 \mathrm{bc}$ & $2.3 \mathrm{a}$ & $1.4 \mathrm{c}$ \\
Amiprophos methyl 10 & $100.0 \mathrm{a}$ & $75.0 \mathrm{bc}$ & $2.3 \mathrm{a}$ & $1.3 \mathrm{c}$ \\
\hline \multicolumn{1}{c}{$p$} & 0.00 & 0.01 & 0.00 & 0.00 \\
\hline \multicolumn{1}{c}{$p$} & &
\end{tabular}

Note. Means in columns followed by the same letter do not differ at significance level $p=0.05$; Duncan test.

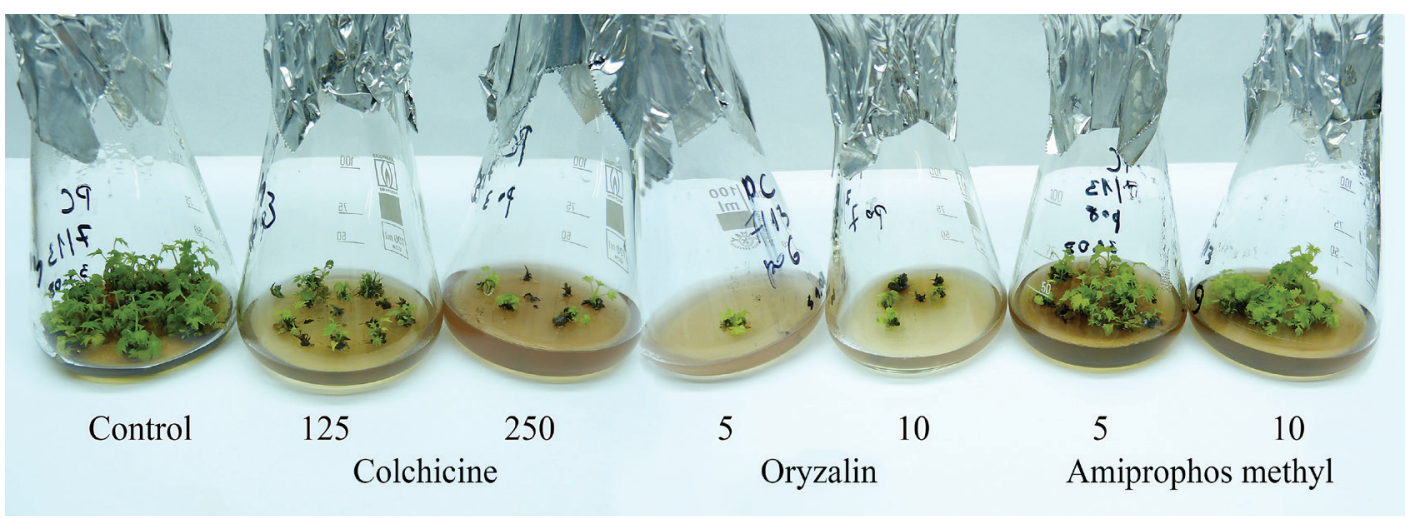

Figure 1. Shoot cultures of blackcurrant cultivar 'Polares' 16 weeks after antimitotic treatment ( $\left.\mathrm{mg} \mathrm{L}^{-1}\right)$ 
after the treatments and shoots of 'Polares' treated with oryzalin at $10 \mathrm{mg} \mathrm{L}^{-1}$ died about 20 weeks following polyploidisation. Colchicine and amiprophos methyl treatments significantly decreased both shoot survival and multiplication rate only in 'Polares', but the phytotoxic effect of these compounds was much weaker compared to trifluralin and oryzalin.

Based on FCM analysis, several homogenous tetraploids and many mixoploids were selected (Table 2, Fig. 2). In 'Gofert', only 6 (2.4\%) homogeneous tetraploids were detected directly (Table 2). Instead, the high percentage $(30.2 \%)$ of mixoploids (ploidy chimeras) was found. Based on histograms of flow cytometry analysis, 42 mixoploids were determined as ploidy chimeras with predominant diploid genotype $(2 \mathrm{x}+4 \mathrm{x})$ and 33 mixoploids with predominant tetraploid genotype $(4 \mathrm{x}+2 \mathrm{x})$ (Table 2, Fig. 2C and D). All the mixoploid shoots were multiplied during two subcultures, and 15 additional homogeneous tetraploids were selected based on FCM. However, these tetraploids derived only from the mixoploids with a predominance of tetraploid genotype $(4 x+2 x)$. Finally, 21 homogenous tetraploids

Table 2. Number of tetraploids of blackcurrant cultivars 'Gofert' and 'Polares' obtained from in vitro polyploidisation

\begin{tabular}{|c|c|c|c|c|c|c|c|}
\hline \multirow[b]{2}{*}{$\begin{array}{l}\text { Antmitotic agents } \\
\qquad \mathrm{mg} \mathrm{L}^{-1}\end{array}$} & \multirow{2}{*}{$\begin{array}{c}\text { Number of } \\
\text { FCM analysed } \\
\text { shoots }\end{array}$} & \multicolumn{2}{|c|}{ Number of mixoploids } & \multicolumn{3}{|c|}{ Number of tetraploids } & \multirow{2}{*}{$\begin{array}{l}\text { Polyploi- } \\
\text { disation } \\
\text { efficiency } \%\end{array}$} \\
\hline & & $2 x+4 x$ & $4 x+2 x$ & $\begin{array}{l}\text { selected } \\
\text { directly }\end{array}$ & $\begin{array}{l}\text { selected from } \\
\text { mixoploids }\end{array}$ & total & \\
\hline \multicolumn{8}{|c|}{ 'Gofert' } \\
\hline Colchicine 125 & 49 & 4 & 6 & 0 & 3 & 3 & 6.1 \\
\hline Colchicine 250 & 34 & 5 & 6 & 2 & 0 & 2 & 5.9 \\
\hline Trifluralin 50 & -* & - & - & - & - & - & - \\
\hline Trifluralin 100 & - & - & - & - & - & - & - \\
\hline Oryzalin 5 & 19 & 3 & 3 & 3 & 2 & 5 & 26.3 \\
\hline Oryzalin 10 & 6 & 1 & 1 & 0 & 0 & 0 & 0 \\
\hline Amiprophos methyl 5 & 54 & 16 & 10 & 1 & 4 & 5 & 9.3 \\
\hline Amiprophos methyl 10 & 87 & 13 & 7 & 0 & 6 & 6 & 6.9 \\
\hline $\begin{array}{ll}\text { Total } \\
\end{array}$ & 249 & 42 & 33 & 6 & 15 & 21 & 8.4 \\
\hline \multicolumn{8}{|c|}{ 'Polares' } \\
\hline Colchicine 125 & 27 & 1 & 0 & 7 & na & 7 & 25.9 \\
\hline Colchicine 250 & 11 & 0 & 0 & 0 & na & 0 & 0 \\
\hline Trifluralin 50 & - & - & - & - & na & - & - \\
\hline Trifluralin 100 & - & - & - & - & na & - & - \\
\hline Oryzalin 5 & 7 & 3 & 0 & 2 & na & 2 & 28.6 \\
\hline Oryzalin 10 & - & - & - & - & na & - & - \\
\hline Amiprophos methyl 5 & 19 & 0 & 0 & 0 & na & 0 & 0 \\
\hline Amiprophos methyl 10 & 67 & 2 & - & 3 & na & 3 & 4.5 \\
\hline Total & 131 & 6 & $\mathbf{0}$ & 12 & na & 12 & 9.2 \\
\hline
\end{tabular}

Note. FCM - flow cytometry; * - all shoots died after these antimitotic treatments; na - not applicable.

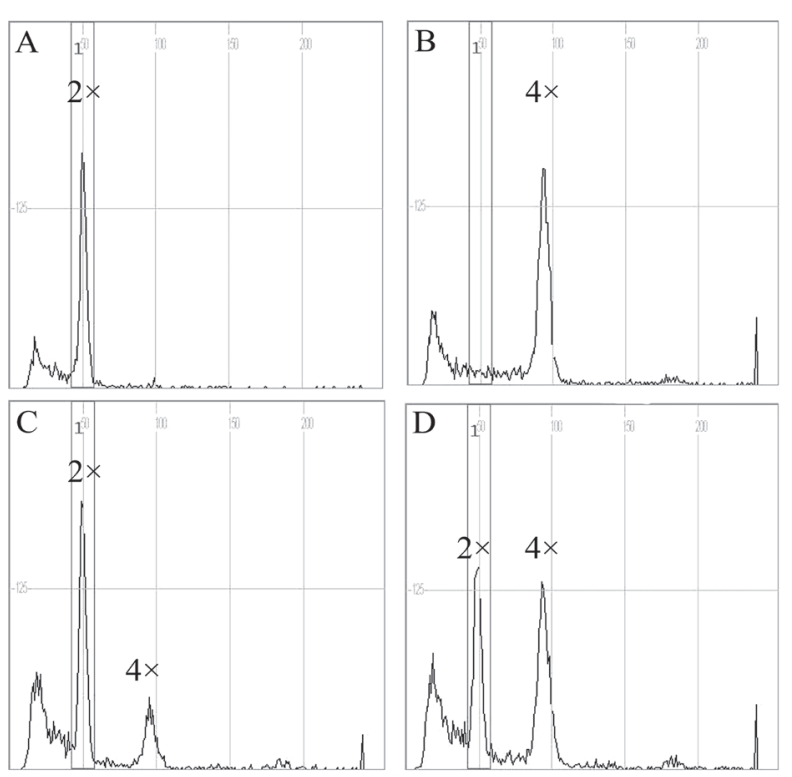

A - diploid, B - tetraploid, C - mixoploid with predominance of diploid genotype, D - mixoploid with predominance of tetraploid genotype

Figure 2. Histograms of flow cytometry analysis of blackcurrant shoots regenerated in vitro after antimitotic treatment of 'Gofert' were obtained with the polyploidisation efficiency on average $8.4 \%$. For 'Polares', 12 tetraploids were detected directly with an average polyploidisation efficiency of $9.2 \%$.

In summary, the higher efficiencies of tetraploid induction were recorded with oryzalin $\left(5 \mathrm{mg} \mathrm{L}^{-1}\right)$, $26.3 \%$ for 'Gofert' and $28.6 \%$ for 'Polares'; $25.9 \%$ with colchicine $\left(125 \mathrm{mg} \mathrm{L}^{-1}\right)$ for 'Polares' and $9.3 \%$ with amiprophos methyl (5 mg L-1) for 'Gofert' (Table 2).

However, the selected tetraploids produced a very low number of shoots on a standard multiplication medium containing BAP; the shoots were short, below 1 $\mathrm{cm}$ in length and attempts to rooting such shoots failed (data not presented). The application of meta-topolin at the concentration of $8 \mu \mathrm{M}$ considerably improved the tetraploid multiplication rate and shoot quality. Results are presented for the 'Gofert' (Table 3, Fig. 3A). The significant differences were recorded for the second subculture, with the highest multiplication rate of 6.4 achieved at $8 \mu \mathrm{M}$ meta-topolin treatment while in the presence of $4 \mu \mathrm{M}$ BAP (control treatment) the multiplication rate was 2.5 . Shoots with the largest leaves were observed in the presence of $4 \mu \mathrm{M}$ meta-topolin. Using the multiplication medium with $8 \mu \mathrm{M}$ metatopolin, each tetraploid was multiplied to $5-15$ shoots 
Table 3. Effect of cytokinins on in vitro shoot multiplication of newly obtained tetraploids of blackcurrant cultivar 'Gofert'

\begin{tabular}{lcc}
\hline \multicolumn{1}{c}{ Cytokinin } & \multicolumn{2}{c}{ Multilication rate } \\
\cline { 2 - 3 } \multicolumn{1}{c}{$\mu \mathrm{M}$} & $1^{\text {st }}$ subculture $2^{\text {nd }}$ subculture \\
\hline BAP 4 (control) & $1.6 \mathrm{~d}$ & $2.5 \mathrm{bcd}$ \\
meta-topolin 2 & $2.3 \mathrm{~cd}$ & $4.0 \mathrm{~b}$ \\
meta-topolin 4 & $1.9 \mathrm{~cd}$ & $3.3 \mathrm{bc}$ \\
meta-topolin 8 & \multicolumn{2}{c}{$0.4 \mathrm{~cd}$} \\
\hline \multicolumn{2}{c}{0.00} \\
\hline Subculture & \multicolumn{2}{c}{0.00} \\
Cytokinin treatment & \multicolumn{2}{c}{0.01} \\
Cytokinin treatment $\times$ subculture & \multicolumn{2}{c}{0.4} \\
\hline
\end{tabular}

Note. BAP - 6-benzylaminopurine; means followed by the same letter do not differ at significance level $p=0.05$; Duncan test. and rooted in vitro (Fig. 3B). Nearly all tetraploid shoots formed roots in vitro, but their acclimatization frequency was markedly lower: $52.0 \%$ for 'Gofert' and 50.0\% for 'Polares', compared to diploid plants of these cultivars: $72 \%$ and $81 \%$, respectively.

Newly obtained six-month-old tetraploid plants differed phenotypically from their diploid counterparts. Due to the higher number of tetraploid plants available for 'Gofert', detailed observations were made for this cultivar. Compared to diploids, tetraploid plants were shorter by more than half and had significantly lower numbers of leaves; the leaf shape was different, and the chlorophyll index was higher by 33\% (Table 4, Fig. 3C).

Table 4. Evaluation of phenotype of blackcurrant tetraploid cultivar 'Gofert' compared to diploid plants

\begin{tabular}{cccccc}
\hline $\begin{array}{c}\text { Ploidy } \\
\text { level }\end{array}$ & $\begin{array}{c}\text { Main shoot length } \\
\mathrm{cm}\end{array}$ & $\begin{array}{c}\text { Shoot diameter } \\
\mathrm{mm}\end{array}$ & $\begin{array}{c}\text { Leave } \\
\text { number }\end{array}$ & $\begin{array}{c}\text { Number of } \\
\text { branches }\end{array}$ & $\begin{array}{c}\text { Relative chlorophyll } \\
\text { content (SPAD) }\end{array}$ \\
\hline $2 \mathrm{x}$ & $14.0 \mathrm{a}$ & $3.8 \mathrm{a}$ & $12.3 \mathrm{a}$ & $3.2 \mathrm{a}$ & $13.3 \mathrm{~b}$ \\
$4 \mathrm{x}$ & $6.2 \mathrm{~b}$ & $4.1 \mathrm{a}$ & $5.9 \mathrm{~b}$ & $0.0 \mathrm{~b}$ & $17.3 \mathrm{a}$ \\
\hline$p$ & 0.00 & 0.31 & 0.00 & 0.00 & 0.01 \\
\hline
\end{tabular}

Note. Measurements done after a six-month growing in a greenhouse; means in columns followed by the same letter do not differ at significance level $p=0.05$; Duncan test.

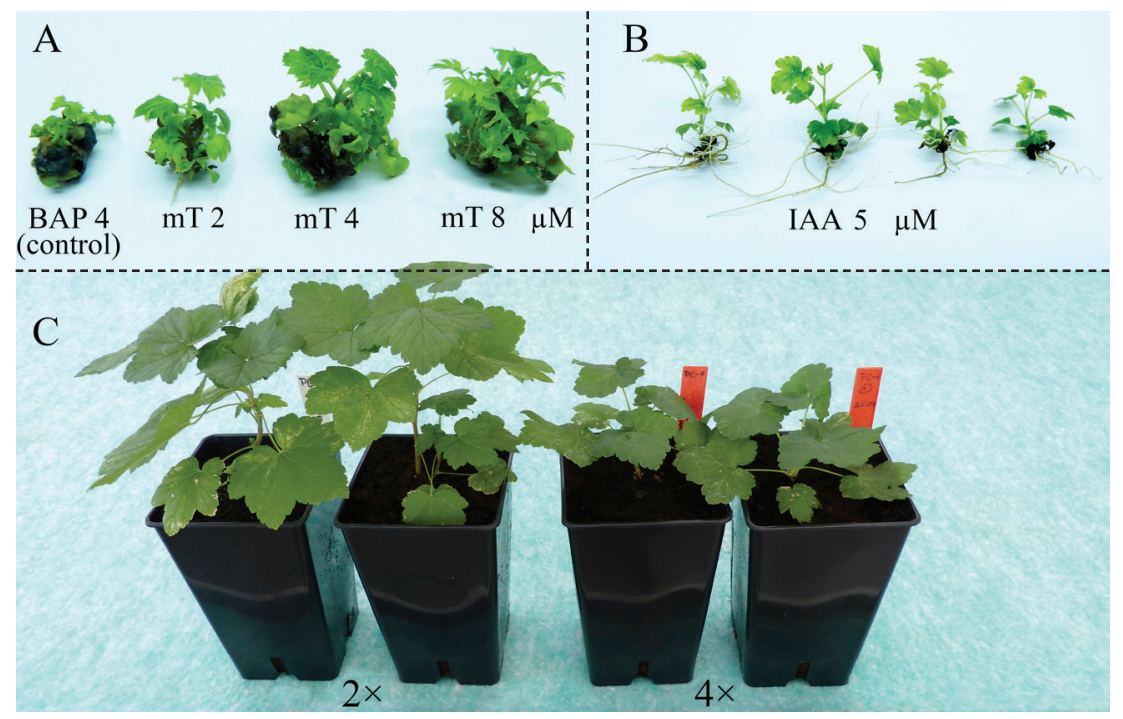

Figure 3. Shoot multiplication, in vitro rooting and plants growing ex vitro of blackcurrant tetraploids cultivar 'Gofert': shoot clumps at the fourth week on multiplication medium containing 6-benzylaminopurine (BAP) or meta-topolin $(\mathrm{mT})(\mathrm{A})$, in vitro rooted shoots in the presence of indole-3-acetic acid (IAA) (B), and plants of diploid and tetraploid plants of the 'Gofert' grown ex vitro for six months (C)

\section{Discussion}

Our study showed the high potential of in vitro polyploidisation using shoot cultures and various antimitotic agents such as colchicine, oryzalin and amiprophos methyl. The latter was used successfully for the blackcurrant polyploidisation for the first time and showed relatively little or no phytotoxic effect. Amiprophos methyl was used for in vitro chromosome doubling of many plant species in order to obtain tetraploids, e.g., of banana (Rodrigues et al., 2011), tulip, daylily and apple (Podwyszyńska, 2012; Podwyszyńska et al., 2015; 2017). In Rosa hybrida, chromosome doubling was induced by an application of trifluralin, amiprophos methyl or oryzalin at a concentration of $6 \mu \mathrm{M}$ and exposure time of $24 \mathrm{~h}$, and no differences were recorded in the activity of these antimitotic agents.

Since only a few tetraploids of the cultivar 'Gofert' were detected directly, all mixoploids were also left and used for further tetraploid selection. Interestingly, the homogenous tetraploids were selected only from mixoploids with higher amount of tetraploid tissue $(4 x+2 x)$. The high mixoploid frequency resulting from polyploidisation of shoot explants is explained by the fact that chromosome doubling can occur, not in all the meristematic cells of the shoot meristems, but in one 
or two cells (Geier, 2012). In such a case, the particular meristematic cells have different ploidy levels and, giving rise to all the tissues and organs, form ploidy chimera. When antimitotic treatment is applied to, e.g., leaf tissue, which does not contain any organized meristems, the shoots developing from individual cells via adventitious organogenesis may be diploid or tetraploid. Similarly, as in our study, high numbers of mixoploids were obtained during polyploidisation of shoot explants in, e.g., Humulus lupulus (Trojak-Goluch, Skomra, 2013) and Malus $\times$ domestica (Podwyszyńska et al., 2017). In apple, the induction of chromosome doubling using leaf explants resulted in only a few mixoploids, compared to the high numbers of homogenous tetraploids obtained after antimitotic treatments of this type of explants (Podwyszyńska et al., 2017). Unfortunately, leaf explants of blackcurrant possess low regeneration potential (Graham, McNicol, 1991; Enevoldsen, 1994; Karjalainen et al., 2001). We postulate that the occurrence of mixoploids, especially those with the predominance of tetraploid tissue, can be considered as a positive phenomenon, since during two months (two multiplication cycles), additional homogenous tetraploids can be selected. This was shown in the present study for blackcurrant as well as recently for apple polyploidisation (Podwyszyńska et al., 2017). Stanys and co-authors (2004) obtained several polyploid plants from isolated embryos of Ribes nigrum and its interspecific hybrids as well as shoot explants of $R$. hudzonianum. These authors recorded much higher polyploidisation efficiency for the treatment with oryzalin at the concentrations of 20-30 $\mu \mathrm{M}$, similar to that used in our studies. However, the treatment with this compound lasted only one day. In our study, oryzalin treatment was applied longer (six days) and probably therefore resulted in higher phytotoxic effects and lower polyploid numbers.

All the tetraploids selected in our study grew very slowly on a standard multiplication medium containing BAP; the shoots were of low quality and not able to root. The substitution of BAP with meta-topolin enabled the multiplication of the obtained tetraploids and their rooting in vitro as well as acclimatization in the greenhouse. During the last decade, this cytokinin has widely been used in micropropagation of many plants improving not only multiplication rate and shoot quality, but also rooting ability and acclimatization efficiency (Wojtania, 2010; Podwyszyńska, Cieślińska, 2018). The positive effect of this cytokinin was ascribed to its fast metabolism in plant tissue (Werbrouck et al., 1996). This cytokinin and its metabolites did not accumulate at over optimal concentrations in plant tissue and did not negatively affect plant development. Thus, the application of meta-topolin for multiplication of tetraploid shoots made it possible to obtain plant material for phenotypic observation.

Some authors have reported phenotype evaluation of blackcurrant autotetraploids derived from in vitro polyploidisation (Sasnauskas et al., 2007; Stanienè et al., 2008). Compared to diploids, one- and two-year-old shoots of tetraploid plants were slightly shorter and contained much lower leaf numbers, but shoot diameter was larger and leaves contained significantly more chlorophyll. Their observations correspond well with the results of our studies on sixmonth-old tetraploid plants. Furthermore, Sasnauskas and co-authors (2007) reported that tetraploid and diploid plants showed a similar resistance level to fungal diseases such as powdery mildew, septoria leaf spot and anthracnose; in tetraploids, pollen was polymorphic with lower germination frequency. Interestingly, these authors reported that tetraploid plants had a slightly smaller number of berries in string. However, the fruits were significantly larger and more homogenous in size, and the berries also contained fewer seeds. The observations concerning fruits of tetraploid blackcurrant correspond well with other reports on fruit features of newly obtained tetraploids, as reviewed by Sattler and co-authors (2016). Sasnauskas and co-authors (2007) confirmed that chromosome doubling in blackcurrant was sensible and reasonable and could be used in the creation of new cultivars with larger fruits.

To date no tetraploid cultivars of blackcurrant have been available. As reviewed by Brennan (1996) and Hjalmarsson and Wallace (2007), in the 60s and 70s of the last century several autotetraploids of blackcurrants were produced and depending on genotype, tetraploidy resulted in many positive features but also in some cases in the negative traits. Thus, tetraploids showed increased flower size and reduced number of flowers per inflorescence, shorter and thicker shoots, sometimes malformed leaves, and smaller fruits with fewer seeds. Besides, tetraploids were usually fertile and used for crossing with diploids that resulted in triploids. On the other hand, several tetraploids with improved disease resistance, later flowering and ripening and enhanced fruit quality were selected by Chuvashina (1972). Hjalmarsson and Wallace (2007) concluded that autopolyploids of blackcurrants generally displayed reduced vigour and fertility, while allopolyploids tended to have increased vigour and were fertile. The good examples of such allotetraploids are the tetraploid hybrids between blackcurrants and gooseberries such as German cultivars of jostaberry (R. nidigrolaria Rud. Bauer \& A. Bauer) being complex-cross (Ribes nigrum $\times R$. grossularia $) \times(R$. nigrum $\times R$. divaricatum) (Bauer, 1986), Swedish cultivar 'Kroma' involving three Ribes species $(R$. nigrum $\times R$. grossularia $) \times(R$. nigrum $\times$ $R$. niveum) (Hjalmarsson, Wallace, 2007) and Russian hybrids 3231 and B 1323/3 (Tikhonova et al., 2015). All these tetraploid hybrids displayed intermediate traits of parental genotypes and had several positive characters such as larger fruits than blackcurrants and increased resistance level to diseases. However, they are not suitable for mass production because these hybrids are not adapted to mechanical harvesting. They are generally used in home gardening. In addition, these hybrids are not as rich in anthocyanins and vitamin $\mathrm{C}$ as blackcurrants.

The neotetraploid clones of blackcurrant obtained in our study require more advanced phenotype evaluation for fertility, resistance to biotic and abiotic stress and fruit parameters that is planned in the next years of the research. Then, the most valuable tetraploid clones will be used for further breeding in order to create improved blackcurrant cultivars with enhanced resistance level to diseases and pests and larger fruits.

\section{Conclusions}

1. Treatments of shoot explants with colchicine at the concentration of $125 \mathrm{mg} \mathrm{L}^{-1}$ and amiprophos methyl at 5 and $10 \mathrm{mg} \mathrm{L}^{-1}$ were relatively highly efficient for the blackcurrant polyploidisation in vitro. 
2. An improvement in the multiplication of blackcurrant shoots of tetraploids can be obtained by using meta-topolin instead of 6-benzylaminopurine (BAP) in a medium. That enables successful rooting and acclimatization of tetraploids in a greenhouse.

3. The newly obtained blackcurrant tetraploids differ significantly from their diploid counterparts. In the first year of cultivation, compared to diploids, tetraploid plants were shorter by more than half and had significantly fewer leaves; the leaf shape was different, and the chlorophyll index was higher by $33 \%$.

\section{Acknowledgements}

This work was supported by the Polish Ministry of Science and Higher Education through statutory funds of the Research Institute of Horticulture, Skierniewice, Poland.

Received 06042018 Accepted 10102018

\section{References}

1. Bauer A. 1986. New results of breeding Ribes nidigrolaria: amphidiploid species hybrids between blackcurrant and gooseberry. Acta Horticulturae, 183: 107-110. https://doi.org/10.17660/ActaHortic.1986.183.14

2. Brennan R. M. 1996. Currant and gooseberries. Janic J., Moore J. M. (eds). Fruit breeding. Vol. II. Vine and small fruits. John Willey and Sons Inc., p. 191-296.

3. Chiche J., Brown S. C., Leclerc J. C., Siljak-Yakovlev S. 2003. Genome size, heterochromatin organisation, and ribosomal gene mapping in four species of Ribes. Canadian Journal of Botany, 81 (11): 1049-1057. https://doi.org/10.1139/b03-088

4. Chuvashina N. P. 1972. Tetraploid forms of black currant creating under influence of colchicines. Culture blackcurrant in the USSR. Moscow, Russia, p. 363-372 (in Russian).

5. Chuvashina N. P. 1980. Cytogenetics and breeding of distant hybrids and polyploids of black currant. Leningrad, Russia, 121 p. (in Russian).

6. D'Hont A., Denoeud F., [...], Wincler P. 2012. The banana (Musa acuminata) genome and the evolution of monocotyledonous plants. Nature, 488: 213-217. https://doi.org/10.1038/nature11241

7. Dziedzic E., Jagła J. 2012. Micropropagation of Rubus and Ribes spp. Protocols for micropropagation of selected economically-important horticultural plants. Methods in Molecular Biology, 994: 149-160. https://doi.org/10.1007/978-1-62703-074-8 11

8. Enevoldsen K. 1994. Ribes nigrum L. (blackcurrant): in vitro culture and the production of flavor compounds. Bajaj Y. P. S. (ed.). Medicinal and aromatic plants. Vol. VI. Springer-Verlag, p. 327-338.

9. Geier T. 2012. Chimeras: properties and dissociation in vegetatively propagated plants. Shu Q. Y. et al. (eds). Plant mutation breeding and biotechnology. CABI, p. 191-201. https://doi.org/10.1079/9781780640853.0191

10. Graham J., McNicol R. J. 1991. Regeneration and transformation of Ribes. Plant Cell, Tissue and Organ Culture, 24: 91-95. https://doi.org/10.1007/BF00039736

11. GUS. 2017. Główny Urząd Statystyczny. Produkcja upraw rolnych i ogrodniczych (in Polish). http://stat.gov.pl/

12. Hjalmarsson I., Wallace B. 2007. Gooseberry and currant in Sweden: history and cultivar development. Janic J. (ed.). Plant Breeding Reviews, vol. 29, p. 145-175.
13. Hias N., Svara A., Keulemans J. W. 2018. Effect of polyploidisation on the response of apple (Malus $\times$ domestica Borkh.) to Venturia inaequalis infection. European Journal of Plant Pathology, 151: 515-526. https://doi.org/10.1007/s10658-017-1395-2

14. Karjalainen R., Välimäki K., Pacot-Hiriart C., Kleemola M., Lehto K. 2001. Optimising of the transformation methods of black currant (Ribes nigrum L.) and development of transgenic resistance against black currant reversion virus. Acta Horticulturae, 560: 169-172. https://doi.org/10.17660/ActaHortic.2001.560.29

15. Lazić T., Ružić D. 2007. Organogenesis in vitro from the leaf of blackberry cv. Čačanska Bestrna. Genetika, 39: 69-78. https://doi.org/10.2298/GENSR0701069L

16. Mason A. S. 2016. Polyploidy and hybridization for crop improvement. Science Publishers, $490 \mathrm{p}$. https://doi.org/10.1201/9781315369259

17. Murashige T., Skoog F. 1962. A revised medium for rapid growth and bio assays with tobacco tissue cultures. Physiologia Plantarum, 15: 473-497. https://doi.org/10.1111/j.1399-3054.1962.tb08052.x

18. Pluta S. 2012. New challenges in the Ribes breeding and production. Acta Horticulturae, 946: 27-35. https://doi.org/10.17660/ActaHortic.2012.946.1

19. Pluta S., Żurawicz E. 2014. 'Gofert' blackcurrant. HortScience, 49: 513-515. https://doi.org/10.21273/HORTSCI.49.4.513

20. Pluta S. Żurawicz E. 2015. 'Polares' blackcurrant. HortScience, 50: 1582-1584. https://doi.org/10.21273/HORTSCI.50.10.1582

21. Pluta S., Żurawicz E., Pruski K. 2012. Suitability of fruits of selected blackcurrant (Ribes nigrum L.) cultivars for fresh market. Journal of Berry Research, 2 (1): 23-31.

22. Podwyszyńska M. 2012. In vitro tetraploid induction in tulip (Tulipa gesneriana L.). Acta Horticulturae, 961: 391-396.

https://doi.org/10.17660/ActaHortic.2012.961.51

23. Podwyszyńska M., Cieślińska M. 2018. Rooting shoots of apple varieties and their tetraploids obtained by the in vitro technique. Acta Scientarum Polonarum Hortorum Cultus, 17: 49-64. https://doi.org/10.24326/asphc.2018.1.5

24. Podwyszyńska M., Gabryszewska E., Dyki B., Stępowska A., Kowalski A., Jasiński A. 2015. Phenotypic and genome size changes (variation) in synthetic tetraploids of daylily (Hemerocallis) in relation to their diploid counterparts. Euphytica, 203: 1-16. https://doi.org/10.1007/s10681-014-1212-3

25. Podwyszyńska M., Sowik I., Machlańska A., Kruczyńska D., Dyki B. 2017. In vitro tetraploid induction of Malus $\times$ domestica Borkh. using leaf or shoot explants. Scientia Horticulturae, 226: 379-388. https://doi.org/10.1016/j.scienta.2017.08.042

26. Reisch B. I., Owens C. L., Cousins P. S. 2012. Grape. Badenes M., Byrne D. (eds). Fruit breeding. Handbook of Plant Breeding. Vol. 8. Springer, p. 225-262.

27. Rodrigues F. A., Soares J. D. R., Santos R. R., Pasqual M., Silva S. O. 2011. Colchicine and amiprophos-methyl (APM) in polyploidy induction in banana plant. African Journal of Biotechnology, 10: 13476-13481.

28. Sasnauskas A., Staniené G., Gelvonauskiene D., Siksnianas T., Stanys V., Bobinas C., Rugienius R., Baniulis D. 2007. Morphological traits in Ribes nigrum polyploids. Acta Horticulturae, 760: 405-408.

29. Sattler M. C., Carvalho C. R., Clarindo W. R. 2016. The polyploidy and its key role in plant breeding. Planta, 243: 281-296. https://doi.org/10.1007/s00425-015-2450-x

30. Sedlák J., Paprštein F. 2012. In vitro establishment and proliferation of red currant cultivars. Horticultural Science, 39: $21-25$.

https://doi.org/10.17660/ActaHortic.2012.946.64 
31. Stanienė G., Šikšnianas T., Stanys V., Šikšnianienė J. B., Morkūnaitè-Haimi Š. 2008. The expression of features of black currant diploid and tetraploid plants. Sodininkystè ir daržininkystè, 27 (4): 67-72 (in Lithuanian).

32. Stanys V., Stanienè G., Šikšnianas T. 2004. In vitro induction of poliploidy in Ribes. Acta Universitatis Latviensis, Biology, 676: 235-237.

33. Tikhonova O. A., Gavrilova O. A., Pupkova N. A. 2015. Morpho-biological features of black currant - gooseberry hybrids in the North-West of Russia. Contemporary Horticulture - Science Theory and Practice on-line journal, 4: 43-60 (in Russian).

34. Trojak-Goluch A., Skomra U. 2013. Artificially induced polyploidisation in Humulus lupulus L. and its effect on morphological and chemical traits. Breeding Science, 63: 393-399.

https://doi.org/10.1270/jsbbs.63.393

35. Vujović T., Ruižić D., Cerović R. 2012. Improvement of in vitro micropropagation of black currant 'Čačanska Crna'. Acta Horticulturae, 946: 123-128.

https://doi.org/10.17660/ActaHortic.2012.946.17
36. Werbrouck S. P. O., Strnad M., Van Onckelen H. A., Debergh P. C. 1996. Meta-topolin an alternative to benzyladenine in tissue culture? Physiologia Plantarum, 98: 291-297. https://doi.org/10.1034/j.1399-3054.1996.980210.x

37. Wojtania A. 2010. Effect of meta-topolin on in vitro propagation of Pelargonium $\times$ hortorum and Pelargonium $\times$ hederaefolium cultivars. Acta Societatis Botanica Poloniae, 79: 101-106. https://doi.org/10.5586/asbp.2010.013

38. Wu J. H., Ferguson A. R., Murray B. G., Jia Y., Datson P. M., Zhang J. 2012. Induced polyploidy dramatically increases the size and alters the shape of fruit in Actinidia chinensis. Annals of Botany, 109 (1): 169-179. https://doi.org/10.1093/aob/mcr256

39. Zhang W., Hao H., Ma L., Zhao C., Yu X. 2010. Tetraploid muskmelon alters morphological characteristics and improves fruit quality. Scientia Horticulturae, 125: 396-400. https://doi.org/10.1016/j.scienta.2010.04.038

ISSN 1392-3196 / e-ISSN 2335-8947

Zemdirbyste-Agriculture, vol. 106, No. 2 (2019), p. 151-158

DOI 10.13080/z-a.2019.106.020

\title{
Juodojo serbento (Ribes nigrum L.) tetraploidụ indukcija in vitro ir preliminarūs fenotipiniai stebẻjimai
}

\author{
M. Podwyszyńska, S. Pluta \\ Skernevicès sodininkystès tyrimų institutas, Lenkija
}

\section{Santrauka}

Tyrimo tikslas - sukurti in vitro poliploidizacijos metodą, skirtą naujų pagerintų juodojo serbento (Ribes nigrum L.) veislių selekcijai. Eksperimento metu naudotos lenkiškos juodojo serbento veislès 'Gofert' ir 'Polares'. Poliploidizacijai ūglių eksplantai buvo inkubuoti 6 dienas tamsoje Murashige ir Skoog terpeje, papildytoje 4,5 $\mu \mathrm{M}$ 6-benzilaminopurino (BAP), 0,3 $\mu \mathrm{M}$ giberelo rūgšties $\left(\mathrm{GA}_{3}\right)$ ir $0,5 \mu \mathrm{M}$ indolo-3-acto rūgšties (IAA), turinčioje viena iš šių antimitotinių medžiagų: kolchicino, trifluralino, orizalino arba amiprofoso metilo. Iš tirtu antimitotiniu medžiagų stipriausias fitotoksinis poveikis buvo nustatytas trifluralino (visi eksplantai žuvo). Buvo gauti abiejų veislių tetraploidai: 21 'Gofert' ir 12 'Polares'. Didesnis tetraploidų indukcijos efektyvumas buvo nustatytas naudojant orizaliną ( $\left.5 \mathrm{mg} \mathrm{L}^{-1}\right)-26,3$ ir 28,6 \% veislèms 'Gofert' ir 'Polares', 25,9\% naudojant kolchiciną (125 $\left.\mathrm{mg} \mathrm{L}^{-1}\right)$ veislei 'Polares' ir 9,3\% naudojant amiprofoso metilą $\left(5 \mathrm{mg} \mathrm{L}^{-1}\right)$ veislei 'Gofert'. Be to, tik $6(2,4 \%)$ homogenišku veislès 'Gofert' tetraploidų buvo atrinkta tiesiogiai. Tačiau šios veislès juoduosiuose serbentuose buvo nustatytas didelis kiekis $(30,1 \%)$ miksoploidų. Visi miksoploidų ūgliai buvo subkultivuoti du kartus. Papildomi 15 homogeniškų tetraploidų buvo atrinkti naudojant srauto citrometrijos analizę miksoploidų ūglių kultūroms, tačiau tik toms, kuriose dominavo tetraploidinis genotipas. Tetraploidizavimo efektyvumas buvo vidutiniškai 8,4 ir 9,2\% veislèms 'Gofert' ir 'Polares'. Naujai gautų tetraploidų in vitro augimas ir ūglių dauginimasis buvo labai prastas terpejje, papildytoje BAP. Todèl, siekiant gauti tetraploidų ūglius, sugebančius šaknytis, ūglių dauginimasis buvo optimizuotas naudojant 6-(3-hidroksibenzilamino)puriną (metatopoliną). BAP pakeitimas metatopolinu terpejje leido greičiau daugintis naujai gautiems tetraploidams, kurie vèliau buvo ịšaknyti in vitro ir auginti šiltnamyje. Tetraploidai fenotipiškai skyrèsi nuo diploidų. Po 6 mènesių auginimo in vitro buvo atlikti tikslūs veislès 'Gofert' augalų matavimai. Palyginus su diploidais, tetraploidų buvo trumpesnès šaknys, skyrèsi lapų forma, jie turẻjo mažiau lapų ir didesni chlorofilo indeksą.

Reikšminiai žodžiai: amiprofoso metilas, chromosomų padvigubėjimas, kolchicinas, metatopolinas, orizalinas. 